\title{
Comparative Effectiveness of Vancomycin and Metronidazole for the Initial Episode of Nonsevere Clostridium Difficle Infection
}

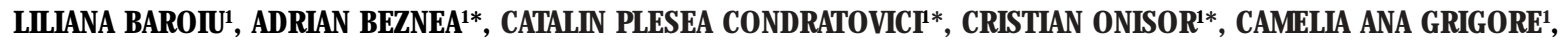 \\ GABI TOPOR ${ }^{1}$, SORIN RUGINA ${ }^{2}$ \\ 'Dunrea de J os University of Galati, Faculty of Medicine and Pharmacy, 47 Domneasca Str., 800008, Galati, Romania \\ 2Ovidius University of Constanta, Faculty of Medicine and Pharmacy, 124 Mamaia Blvd., 900527, Constanta, Romania
}

The infection with Clostridium difficile (CDI), which appeared at epidemic level, after acquiring the germ of some fluoroquinolone resistance genes, initially considered nosocomial infection and adverse effect postantibiotic therapy, is affecting more and more people without risk factors and extending into the community. This paper proposes an analysis of the two main antibiotics used in therapy: metronidazole and vancomycin, the evidence of efficacy in the literature and the chemical stability of antibiotics in simulated gastrointestinal fluid. Based on UV-Vis absorption spectra, it can be considered that there are no major changes in the chemical structure of the investigated drugs in the presence of gastro-duodenal conditions. Clinical impact of comparative treatment with metronidazole and vancomycin has also been studied, in a group of $720 \mathrm{CDI}$ patients hospitalized during the period 1.01.2017-31.12.2018 in the Clinical Hospital St. Parascheva of Infectious Diseases Galati. From this group, two subgroups were selected, one of 284 patients receiving oral vancomycin treatment and one group of 62 patients receiving oral metronidazole for an initial nonsevere episode of CDI. The number of days from the beginning of the treatment until the normalization of the stool, the length of hospitalization, the number of days of antibiotic treatment and the percentage of relapses were comparable in the two groups, the percentage of deaths in the first 30 days from the episode of CDI was higher in the vancomycin-treated group, probably due mainly to the severe comorbidities of these patients. The conclusion of the study is that the treatments with metronidazole and vancomycin, of the initial episode, nonsevere of $\mathrm{CDI}$ are comparable as a therapeutic response, provided that the patients treated with metronidazole do not associate hepatic, renal or neurological impairment due to the risk of adverse reactions.

Key words: Clostridium difficile, metronidazole, vancomycine, chemical stability, UV-Vis spectra

Clostridium difficile infection (CDI) is a therapeutic challenge at this time, from the point of view of the few antibiotics active on this germ, the possibility of evolution of infection to toxic megacolon forms, high rates of relapse and mortality, and multiple comorbidities of these patients requiring complex concomitant therapy. Treatment of the first episode, nonsevere, of CDI, is very important because it affects the subsequent clinical outcome in terms of both the duration of the episode of the disease and the occurrence and severity of the possible recurrence or death after CDI. The firstCDI therapy guides, including the current Romanian guide, recommend for this first nonsevere episode of CDI, oral methronidazole 10-14 days, of first intention, the latest CDI therapy guide written by American Society of Infectious Diseases and Epidemiology in 2017 recommends for the first intention, oral vancomycin or oral fidaxomicin and only if the access to vancomycin or fidaxomicin is limited, to use metronidazole. Metronidazole, 2-methyl-5-nitroimidazole-1-ethanol- $\mathrm{C}_{6} \mathrm{H}_{9} \mathrm{~N}_{3} \mathrm{O}_{3}$, Figure 1 , is an synthetic antibiotic with activity spectrum on anaerobic germs, including Clostridium difficile, parasites and Helicobacter pylori.

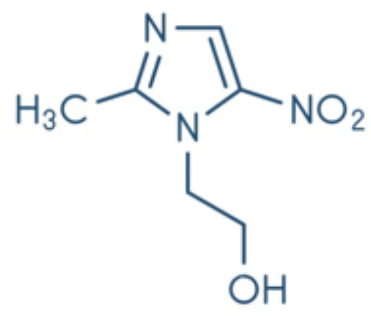

Fig. 1. Metronidazole Chemical Structure
Metronidazole requires intracellular enzymatic activation in the susceptible anaerobic bacteria (which holds these enzymes) to become an active metabolite, bactericide. Thus, under the action of pyruvate-feredoxinoxidoreductase, metronidazole forms radicals of the type of nitrogen oxides, with the oxidation of feredoxin to flavoxoxin. This metabolite has the ability to break bacterial DNA and consequently cause cell death.

Pharmacokinetics of oral form is: rapid absorption, approximately $80 \%$ in the first hour, with similar plasma concentrations to intravenous administration at equivalent doses; approximately $100 \%$ bioavailability, not significantly modified by food; effective plasma concentrations, one hour after administration; the half-life is 8 to 10 hours; plasma protein binding is small: less than $10-20 \%$. Distribution is fast and important, similar plasma concentrations are reached in: lungs, kidneys, liver, skin, bile, cerebrospinal fluid, saliva, seminal fluid, vaginal discharge. Metronidazole crosses the placental barrier and is excreted in breast milk. Metabolism is predominantly by hepatic oxidation resulting in two active metabolites. It concentrates intensely in the liver and the bile. It is weakly concentrated in the intestine. Elimination is predominantly urinary, approximately $35-65 \%$ of the administered dose, with faeces eliminating $6-15 \%$ of the dose. By hemodialysis, metronidazole is rapidly eliminated [1]. Adverse reactions are mainly neuropsychiatric, very rare, such as: mental disorders including confusion and hallucinations, encephalopathy (manifested by, for example, confusion, fever, headache, hallucinations, paralysis, light sensitivity, visual and movement disorders, torticolis), subacute cerebellar syndrome (manifested by, for example, ataxia, dysarthria, impaired walking, nystagmus and tremor), drowsiness, dizziness, seizures,

\footnotetext{
* email: adrianbeznea@hotmail.com, Phone: 0040727394081; catalinplesea@yahoo.com; cristi.onisor@gmail.com
} 
headaches that are reversible upon discontinuation of treatment [1]. Also, the manufacturer recommends cautious use in patients with severe, chronic or progressive central and peripheral neurological disorders due to the risk of neurologic disorders aggravation and prolonged treatment, the need to monitor the occurrence of signs of central neuropathy adverse reactions or peripheral (such as paraesthesia, ataxia, dizziness, convulsions) [2]. Subsequent clinical studies have observed metronidazoleinduced neurotoxicity and encephalopathy in patients with cirrhosis $[3,4]$ and the American CDI treatment guide draw attention to prudence in administration of metronidazole over 10 days due to the risk of cumulative and potentially irreversible neurotoxicity [5]. Other side effects that may occur include: leukopenia, thrombocytopenia, anemia; hypersensitivity reactions such as pruritus, urticaria, fever, angioedema, anaphylactic shock; visual disturbances, diplopia and myopia; nausea, vomiting, bitter or metallic taste, anorexia, elevated liver enzymes (AST, ALT, alkaline phosphatase), cholestatic or mixed hepatitis, jaundice, pancreatitis, arthralgia, myalgia, dark urine reversible upon discontinuation of treatment and possible exacerbation of preexisting hepatic encephalopathy symptoms during metronidazole administration [2]. The non-recommended associations are: disulfiram, ethyl alcohol, lithium. The associations that require precautions are: oral anticoagulants, phenobarbital, phenytoin, 5-fluorouracil, busulfan, cyclosporine [1]. Metronidazole is usually administrated as tablets for nonsevere forms of illness while the intravenous way of administration is preffered for severe infections such as toxic megacolon [6].

Vancomycin- $\mathrm{C}_{66} \mathrm{H}_{75} \mathrm{Cl}_{2} \mathrm{~N}_{9} \mathrm{O}_{2,}$ Figure 2 , is an intravenous glycopeptide for severe, active infection against grampositive bacteria such as staphylococci, streptococci, enterococci, pneumococci, considered as a reserve antibiotic, the oral form is only indicated in CDI, by the first intention. Vancomycin is a branched glycosylated tricyclic non-biosomal peptide produced by fermenting the species of Actinobacteria Amycolatopsis orientalis (formerly Nocardia orientalis). Vancomycin hydrochloride is the active molecule with the following mechanism of action: it inhibits peptidoglycan synthesis from the bacterial cell wall by binding to the $D$-alanyl-D-alanine portion of the cell wall precursors. This leads to the activation of bacterial autolysins that destroy the cell wall by lysis. Vancomycin can also modify the permeability of bacterial cytoplasmic membranes and may selectively inhibit RNA synthesis with ultimate bactericidal action [8].

Pharmacokinetics of vancomycin is: systemic absorption in oral administration is negligible, butcan occur with increased intestinal permeability for inflammatory bowel disease or pseudomembranous colitis caused by Clostridium difficile, possibly associated with renal impairment requires monitoring of serum vancomycin concentrations. Thus, adverse effects noted for parenteral administration of vancomycin may occur in patients with increased intestinal permeability and possibly associated renal failure. The most important adverse effects are nephrotoxicity and ototoxicity, and the association of aminoglycoside in patients with renal impairment increases the risk of these adverse effects [9].

Elimination is exclusively in the faeces, no blood concentrations have been detected after oral dosing, and urinary recovery did not exceed $0.76 \%$, whereas high concentrations of vancomycin are found in faeces ( $>3100$ $\mathrm{mg} / \mathrm{kg}$ at doses of $2 \mathrm{~g} /$ day) [8].

Given that in Romania we do not have the pharmaceutical form of capsules available, but the active substance in both capsules and powders from the vials for iv use is vancomycin hydrochloride and we use in the clinic, the powder in the vial for iv use, dissolved for oral administration, the stability of the solutions is important.

After reconstitution and dilution, the chemical and physical stability of the product has been demonstrated for $48 \mathrm{~h}$ at room temperature $\left(<25^{\circ} \mathrm{C}\right)$ and at temperatures between 2 and $8^{\circ} \mathrm{C}$. From a microbiological point of view, the drug should be used immediately. If not used immediately, the storage period should not exceed $24 \mathrm{~h}$ at temperatures between 2 and $8^{\circ} \mathrm{C}$ and reconstitution/dilution should be carried out under controlled conditions and validated as aseptic [9].

The recommendations of the latest treatment guide for CDI, published by the Infectious Diseases Society of America (IDSA) and the Society for Healthcare Epidemiology of America (SHEA) in 2017 recommend for the treatment of the initial nonsever CDI episode of first-

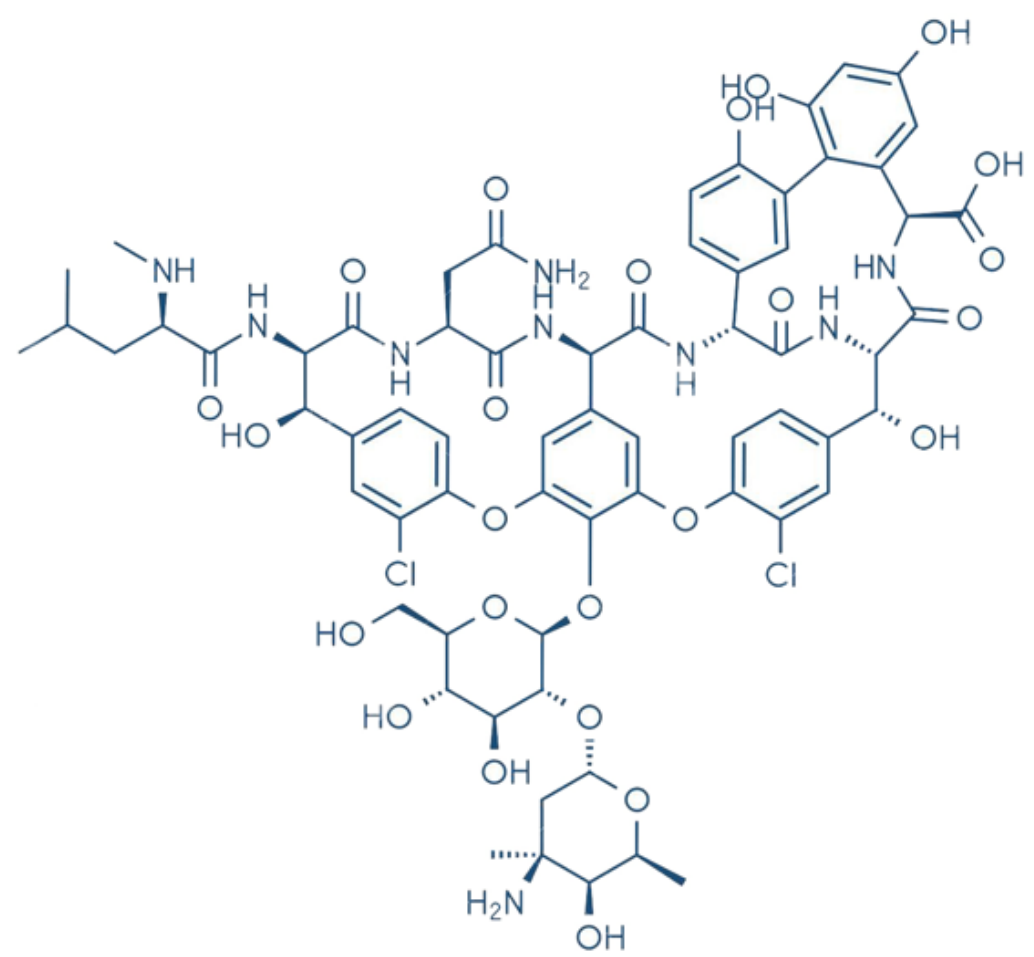

Fig. 2. Vancomycin -Chemical Structure [7] 
line, vancomycin or fidaxomycin and only in the case in which access to vancomycin or fidaxomicin is limited, metronidazole should be used. The dose of vancomycin is $125 \mathrm{mg}$ orally 4 times a day, fidaxomicin is $200 \mathrm{mg}$ twice daily and metronidazole $500 \mathrm{mg}$ orally 3 times a day for 10 days. It is recommended to avoid repeat or prolonged cures of metronidazole due to the cumulative and potentially irreversible risk of neurotoxicity [5]. Several randomized clinical trials emphasized the therapeutical superiority of vancomycine versus metronidazole [10-12]. Almost all randomized trials compared 10-day antibiotic regimens. If patients improved their symptoms but did not have a symptom resolution within 10 days, consideration should be given to extending the duration of treatment to 14 days [13]. It is also recommended to limit the use of oral metronidazole to a single cycle in an initial non-severe CDI episode due to neurotoxicity case reports following prolonged or repeated use $[3,4]$.

\section{Experimental part}

\section{Materials and methods}

The chemical stability of vancomycin and metronidazole in acidic conditions was evaluated using simulated gastrointestinal fluid. The simulated gastrointestinal fluid was obtained by mixing the equal volumes of two solutions. The first solution was obtained using $5 \mathrm{~g} / \mathrm{L} \mathrm{NaCl}$ and $3 \mathrm{~g} / \mathrm{L}$ pepsin and the $\mathrm{pH}$ was adjusted to 2 . The second solution was composed of $5 \mathrm{~g} / \mathrm{L} \mathrm{NaCl}, 3$ $\mathrm{g} / \mathrm{L}$ pancreatin and $0.45 \mathrm{~g} / \mathrm{L}$ bile and $\mathrm{pH}$ was adjusted to 8 . The $\mathrm{pH}$ of the final gastrointestinal fluid, obtained by mixing the two mentionated solutions, was adjusted to 2.5 [14]. The UV-Vis spectra were recorded for the drug solutions and drug solutions in simulated gastrointestinal conditions at different time intervals after their mixing.
We conducted a prospective observational study of 720 CDI patients admitted between 1.01.2017-31.12.2018 in the St. Parascheva Clinic Hospital of Infectious Diseases Galati. Of these, 385 patients ( $53.47 \%$ ) had a first episode, nonsevere of CDI. Of these 385 patients, two groups were formed, the first of 284 patients $(73.76 \%)$ treated with oral vancomycin, 125mg at 6 hours and the second of 62 patients (16.10\%), with oral metronidazole, $500 \mathrm{mg}$ at 8 hours and comparative data were analyzed. The other 39 patients (10.12\%) received between 1 and 4 days of oral metronidazole treatment and due to the lack of favorable evolution, they changed to oral vancomycin therapy and were not included in the study. In these two groups, comparative studies were performed: demographic data, comorbidity profile (quantified by Charlson score), severity of the episode of CDI (quantified by ATLAS score, length of hospitalization), therapeutic response (quantified by the number of days from the start of therapy to stool normalization, the number of relapses and deaths) and were statistically analyzed using the MedCalc program.

\section{Results and discussions}

The UV-Vis spectra of vancomycin and metro-nidazole were recorded from their aqueous solutions in 170-800 $\mathrm{nm}$ range. All the absorption bands of the tw o investigated compounds, as well as the components of the simulated gastrointestinal juice were observed in the UV domain, Figures 3 - 5. No absorption bands in visible range were observed.

No significant changes or frequency shift of the absorption bands of investigated drugs can be observed after mixing with simulated gastrointestinal fluid.

The characteristic absorbance intensity of the initial and mixed solutions is illustrated in the Table 1.

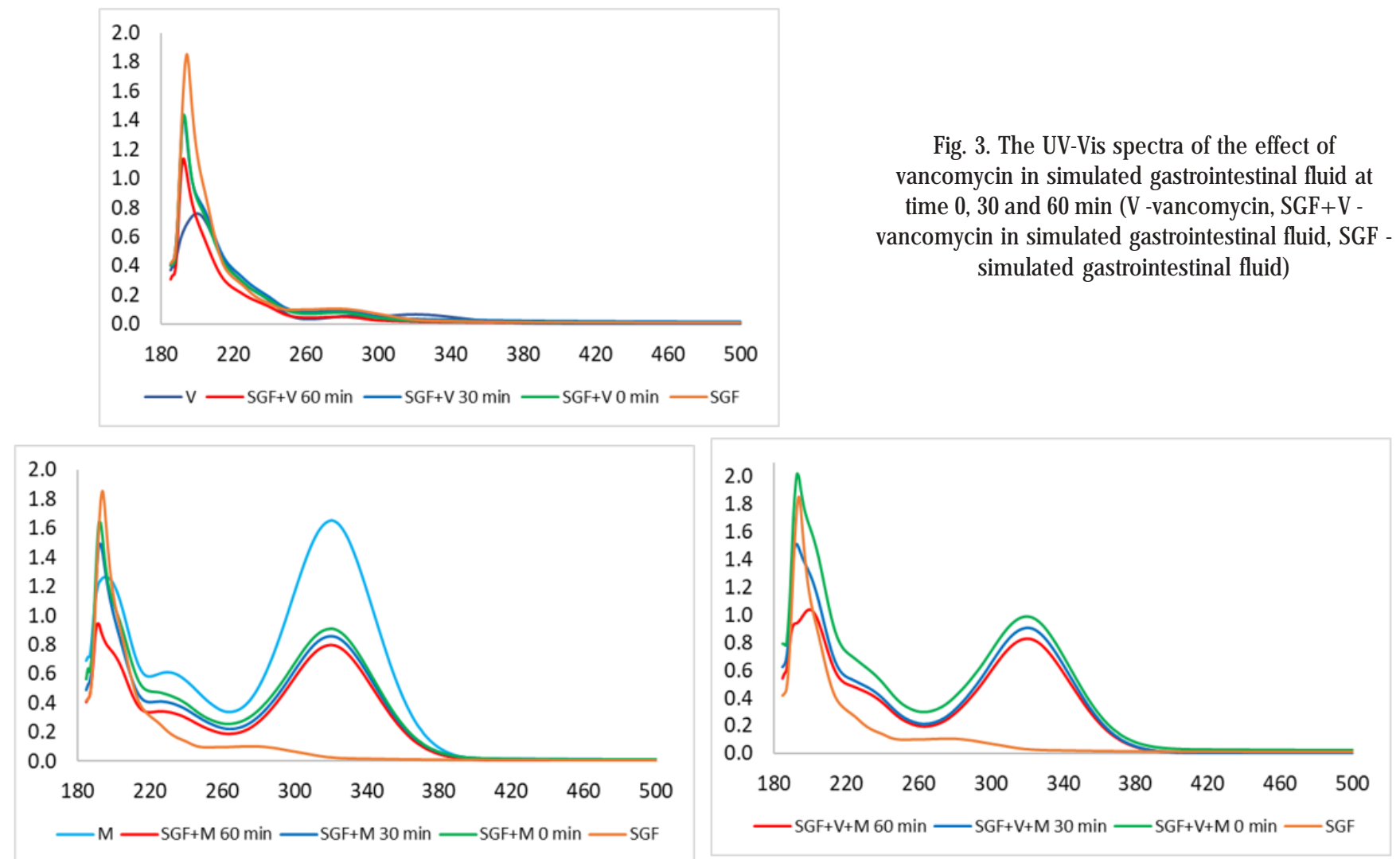

Fig. 4. The UV-Vis spectra of the effect of metronidazole in simulated gastrointestinal fluid at time 0,30 and $60 \mathrm{~min}(\mathrm{M}$ -

metronidazole, SGF+M - metronidazole in simulated gastrointestinal fluid, SGF - simulated gastrointestinal fluid)

Fig. 5. The UV-Vis spectra of the effect of vancomycin and metronidazole in simulated gastrointestinal fluid at time 0,30 and 60 min (V -vancomycin, $\mathrm{M}$ - metronidazole, SGF+V+M - vancomycin and metronidazole in simulated gastrointestinal fluid, SGF - simulated gastrointestinal fluid) 
A hypsochromic effect [15] and a decrease of absorbance intensity was observed when the drugs were mixed with simulated gastrointestinal solutions, possible due to the protonation of the nucleophilic drug groups in the acidic conditions. In conclusion, based on UV-Vis absorption spectra, it can be considered that there are no major changes in the chemical structure of the investigated drugs in the presence of gastro-duodenal conditions, which could affect their efficiency in the treatment. This evidence is extremely important in the current clinical context in which we used vancomycin hydrochloride made for intravenous use, in clinic, for oral use.

The prospective observational study used for enrollment in the initial nonsevere episode of CDI group, the patients with a first episode of disease, with a total leukocyte count of less than $15000 / \mathrm{mm} 3$ and serum creatinine below 1.5 $\mathrm{mg} / \mathrm{dL}$, at admission.

The characteristics of the patients from the two groups are shown in Table 2.

The metronidazole-treated group was younger than the vancomycin-treated group (statistically significant) and the mean age was below 65 years, age with risk of CDI. The group treated with vancomycin had an average age of over 65 years, also found in the first risk interval for high severity of the episode of CDI quantified by the Atlas score (60-79 years) [16]. In both groups, women from the urban area predominated. The urban origin environment predominates due to the easier access to the medical care units and with this, the increase of life expectancy but also the

Table 1

THE $\lambda_{\max }(\mathrm{nm}) /$ ABSORBANCE INTENSITY OF THE WORKING SOLUTIONS AT TIME 0, 30 AND $60 \mathrm{~min}$

\begin{tabular}{|c|c|c|c|c|c|c|c|}
\hline \multirow{3}{*}{$\begin{array}{l}\text { Name of solution } \\
\text { Simulated gastrointestinal } \\
\text { fluid }\end{array}$} & & & \multicolumn{5}{|c|}{$\lambda_{\max }(\mathrm{nm}) /$ absorbance intensity } \\
\hline & \multicolumn{2}{|c|}{ Time 0} & $\begin{array}{l}\text { Possible functional } \\
\text { groups }\end{array}$ & \multicolumn{2}{|c|}{$\begin{array}{c}\text { Time } \\
30 \text { minutes }\end{array}$} & \multicolumn{2}{|c|}{$\begin{array}{l}\text { Time } \\
60 \text { minutes }\end{array}$} \\
\hline & $\begin{array}{l}194.0 \\
/ 1.8532\end{array}$ & - & $\begin{array}{l}=\mathrm{C}=\mathrm{C}= \\
-\mathrm{O}-,-\mathrm{N}-,-\mathrm{S}-\end{array}$ & - & - & - & - \\
\hline Vancomycin & $\begin{array}{l}200.0 \\
/ 0.7599\end{array}$ & $\begin{array}{l}320.0 \\
10.0653\end{array}$ & $\begin{array}{l}-\mathrm{O}-,-\mathrm{N}-,-\mathrm{S}- \\
=\mathrm{C}=\mathrm{C}=,=\mathrm{C}=\mathrm{O},=\mathrm{C}=\mathrm{N}-\end{array}$ & - & - & - & - \\
\hline Metronidazole & $\begin{array}{l}196.0 \\
11.2630 \\
230.0 \\
10.6087\end{array}$ & $\begin{array}{l}321.0 \\
/ 1.6505\end{array}$ & $\begin{array}{l}-\mathrm{O}-,-\mathrm{N}-,-\mathrm{S}- \\
=\mathrm{C}=\mathrm{C}=,=\mathrm{C}=\mathrm{O},=\mathrm{C}=\mathrm{N}-\end{array}$ & - & - & - & - \\
\hline $\begin{array}{l}\text { Simulated gastrointestinal } \\
\text { fluid and vancomycin }\end{array}$ & $\begin{array}{l}192.0 \\
/ 1.4328\end{array}$ & - & $\begin{array}{l}=\mathrm{C}=\mathrm{C}= \\
-\mathrm{O}-,-\mathrm{N}-,-\mathrm{S}-\end{array}$ & $\begin{array}{l}192.0 \\
/ 1.4296\end{array}$ & - & $\begin{array}{l}192.0 \\
/ 1.1377\end{array}$ & - \\
\hline $\begin{array}{l}\text { Simulated gastrointestinal } \\
\text { fluid and metronidazole }\end{array}$ & $\begin{array}{l}192.0 \\
/ 1.6400\end{array}$ & $\begin{array}{l}320 \\
10.9104\end{array}$ & $\begin{array}{l}-\mathrm{O}-,-\mathrm{N}-,-\mathrm{S}- \\
=\mathrm{C}=\mathrm{C}=,=\mathrm{C}=\mathrm{O},=\mathrm{C}=\mathrm{N}-\end{array}$ & $\begin{array}{l}193.0 \\
/ 1.4903\end{array}$ & $\begin{array}{l}320.0 \\
10.8585\end{array}$ & $\begin{array}{l}192.0 \\
/ 0.9454\end{array}$ & $\begin{array}{l}320.0 \\
10.8007\end{array}$ \\
\hline $\begin{array}{l}\text { Simulated gastrointestinal } \\
\text { fluid, ancomycin and } \\
\text { etronidazole }\end{array}$ & $\begin{array}{l}193.0 \\
/ 2.0166\end{array}$ & $\begin{array}{l}320.0 \\
10.9896\end{array}$ & $\begin{array}{l}-\mathrm{O}-,-\mathrm{N}-,-\mathrm{S}- \\
=\mathrm{C}=\mathrm{C}=,=\mathrm{C}=\mathrm{O},=\mathrm{C}=\mathrm{N}-\end{array}$ & $\begin{array}{l}193.0 \\
/ 1.5125\end{array}$ & $\begin{array}{l}320.01 \\
0.9097\end{array}$ & $\begin{array}{l}200 \\
/ 1.0392\end{array}$ & $\begin{array}{l}320.0 \\
0.8292\end{array}$ \\
\hline
\end{tabular}

\section{Table 2}

THE CHARACTERISTICS OF THE PATIENTS TREATED WITH VANCOMYCIN, METRONIDAZOLE AND STATISTICAL CORRELATION

\begin{tabular}{|c|c|c|c|}
\hline & $\begin{array}{l}\text { First nonsevere } \\
\text { episode of CDI } \\
\text { treated with } \\
\text { vancomycin }\end{array}$ & $\begin{array}{l}\text { First nonsevere } \\
\text { episode of CDI } \\
\text { treated with } \\
\text { metronidazole }\end{array}$ & $\begin{array}{l}\text { Statistical correlation } \\
\text { Metronidazole / } \\
\text { Vancomycin } \\
\text { (difference) }\end{array}$ \\
\hline Female Gender \% & $60.56 \%$ & $54.83 \%$ & $5.73 \%(\mathrm{p}=0.4902)$ \\
\hline Urban living area $\%$ & $67.25 \%$ & $67.74 \%$ & $0.49 \%(p=0.9403)$ \\
\hline $\begin{array}{l}\text { Age-arithmetic average /lowest value-highest } \\
\text { value/median } \\
\text { (years old) }\end{array}$ & $\begin{array}{l}65.75 \\
1-91 \\
67\end{array}$ & $\begin{array}{l}57 \\
19-83 \\
59.5\end{array}$ & $8.75(\mathrm{p}=0.0001)$ \\
\hline $\begin{array}{l}\text { Charlson score } \% \\
0-4 \\
5-6 \\
7-14\end{array}$ & $\begin{array}{l}52.46 \% \\
24.29 \% \\
23.23 \%\end{array}$ & $\begin{array}{r}72.58 \% \\
19.35 \% \\
8.06 \%\end{array}$ & $\begin{array}{r}20.12 \%(p=0.0059) \\
4.94 \%(p=0.5049) \\
15.17 \%(p=0.0122)\end{array}$ \\
\hline $\begin{array}{l}\text { Consumption of antibiotics before the beginning of } \\
\text { CDI }\end{array}$ & $64.43 \%$ & $75.80 \%$ & $11.37 \%(p=0.1165)$ \\
\hline $\begin{array}{l}\text { Consumption of protony pump inhibitors before the } \\
\text { beginning of CDI }\end{array}$ & $30.28 \%$ & $25.80 \%$ & $4.48 \%(\mathrm{p}=0.5842)$ \\
\hline $\begin{array}{l}\text { Abdominal surgery in the last } 8 \text { weeks before the } \\
\text { onset of the disease }\end{array}$ & $10.21 \%$ & $9.67 \%$ & $0.54 \%(p=0.9166)$ \\
\hline $\begin{array}{l}\text { ATLAS score } \% \\
0-2 \\
3-5\end{array}$ & $\begin{array}{l}70.77 \% \\
29.22 \%\end{array}$ & $\begin{array}{l}93.54 \% \\
6.45 \%\end{array}$ & $\begin{array}{l}22.77 \%(\mathrm{p}=0.0003) \\
22.77 \%(\mathrm{p}=0.0003)\end{array}$ \\
\hline $\begin{array}{l}\text { Hospitalization -Arithmetic average lowest value- } \\
\text { highest value/median (days) }\end{array}$ & $\begin{array}{l}7.96 \\
1-43 \\
7\end{array}$ & $\begin{array}{l}6.45 \\
1-15 \\
7\end{array}$ & $1.50(\mathrm{p}=0.0044)$ \\
\hline $\begin{array}{l}\text { The number of days until the stool is normalized } \\
\text { Arithmetic average /lowest value-highest } \\
\text { value/median (days) }\end{array}$ & $\begin{array}{l}4.49 \\
1-16 \\
4\end{array}$ & $\begin{array}{l}3.56 \\
1-9 \\
3\end{array}$ & $0.93(\mathrm{p}=0.0080)$ \\
\hline $\begin{array}{l}\text { Duration of treatment Arithmetic average /lowest } \\
\text { value-highest value/median (days) }\end{array}$ & $\begin{array}{l}9.89 \\
1-18 \\
10\end{array}$ & $\begin{array}{l}8.59 \\
4-16 \\
9\end{array}$ & $1.29(\mathrm{p}=0.0002)$ \\
\hline Relapses & $9.15 \%$ & $9.67 \%$ & $0.52(\mathrm{p}=0.9093)$ \\
\hline Deaths & $7.39 \%$ & 0 & $7.39 \%(p=0.0555)$ \\
\hline
\end{tabular}


appearance of the comorbidities characteristic of the advanced age and the immunocompromised status and also of the infections associated with the medical care, including CDI.

In order to measure the spectrum of comorbidities, we used the Charlson score [17], which appreciates the hope of survival at 10 years, depending on the cumulative comorbidities. The highest scores of comorbidities are noted in the group with vancomycin (statistically significant), because we treated patients with less comorbidities with metronidazole and especially without neurological, hepatic and renal impairment due to the risk of adverse reactions. Antibiotic use in the last 8 weeks prior to the onset of CDI was higher in the metronidazoletreated group and proton pump inhibitors consumption and abdominal surgery also in the last 8 weeks prior to the onset of CDI were higher in the vancomycin-treated group.

In order to measure the severity of the disease episode, the Atlas score and the length of hospitalization were calculated.

The Atlas score and the duration of hospitalization showed that patients treated with vancomycin had statistically significantly higher severity, of the disease episode.

The response to the treatment was quantified taking into account the number of days from the beginning of the treatment until the normalization of the stool (the number of stool should be maximum 2/ day, type 1-4 Bristol scale [18]), required number of days of antibiotic treatment, the number of relapses in the first 8 weeks after the initial episode of CDI, and the number of deaths occurring in the first 30 days after the episode of CDI. Patients treated with metronidazole needed a slightly shorter period of time for stool normalization and as a consequence needed less days of specific antibiotic treatment (statistically significant). The relapse rate was slightly higher in the metronidazole-treated group but the death rate was higher in the vancomycin-treated group possibly due to the severe comorbidities of this group.

\section{Conclusions}

Young adult patients with few comorbidities were treated with metronidazole because of the low risk of adverse effects while patients with multiple comorbidities were treated with vancomycin. The lower number of deaths in the metronidazole-treated group than in the vancomycin-treated group is mainly due to the severe comorbidities of patients in the second group. The duration of hospitalization, the duration of treatment, the length of time to normalization of the stool, the relapse rate, are comparable in the two groups, so the conclusion of the study is that metronidazole can also be used for a first nonsevere episode of $\mathrm{CDI}$, with good therapeutic response, provided that the patient does not associate hepatic or renal failure and neurological impairment. Vancomycin remains the firstchoice for the patients with multiple comorbidities and the patients with disease episodes of high severity, especially as the UV-Vis spectra study certifies the vancomycin's stability in simulated gastrointestinal fluid and consequently its therapeutic efficacy.

\section{References}

1. *** Autorizape de punere pe piata Flagyl 250 mg, https://www.anm.ro/ I_RCP/RCP_7610_30.04.15.pdf.

2. *** Rezumatul caracteristicilor produsului Metronidazol Braun 5 $\mathrm{mg} / \mathrm{ml}$, https://be-healthy.ro/metronidazol-braun-5-mg-ml-solutieperfuzabila-rezumatul-caracteristicilor-produsului/.

3. YAMAMOTO, T., ABE, K., ANJIKI, H., ISHII, T., KUYAMA, Y., J Clin Med Res, 4, 2012, p. 295.

4. KNORR, J.P., JAVED, I., SAHNI, N., CANKURTARAN, C.Z., ORTIZ, J.A., Case Reports Hepatol, 2012, doi: 10.1155/2012/209258.

5. McDONALD, L.C., GERDING, D.N. et al., Clinical Infectious Diseases, 66(7), 2018, p. el.

6. TIUTIUCA, C., DRAGANESCU, M., IANCU, A., CHESARU, B.I., ARBUNE, M., MAFTEI, N., POPESCU, E., Rev. Chim. (Bucharest), 68, no. 5, 2017, p. 1122.

7. *** Vancomycin, https://pubchem.ncbi.nlm.nih.gov/compound/ Vancomycin\#section=2D-Structure.

8. *** Rezumatul caracteristicilor produsului Vancomicina,https:// ec.europa.eu/health/documents/community-register/2017/ 20170921139384/anx_139384_ro.pdf.

9. *** Vancomicinã $\bar{P}$ harmaS̄wiss, $500 \mathrm{mg} / 1000 \mathrm{mg}$,

https://www.csid.ro/medicamente/vancomicina-pharmaswiss-500-mg1000-mg-pulbere-pentru-solutie-perfuzabila-11364546.

10. ZAR, F.A., BAKKANAGARI, S.R., MOORTHI, K.M., DAVIS, M.B., Clin Infect Dis, 45, 2007, p. 302.

11. J OHNSON, S., LOUIE, T.J., GERDING, D.N. et al., Clin Infect Dis, 59, 2014, p. 345.

12. SIEGFRIED, J., DUBROVSKAYA, Y., FLAGIELLO, T. et al., Infect Dis Clin Pract, 24, 2016, p. 210.

13. COHEN, S.H., GERDING, D.N., JOHNSON, S. et al., Infect Control Hosp Epidemiol, 31, 2010, p. 431.

14. KOS, B., SUSKOVIC, J., GORETA, J., MATOSIC, S., Food technol. biotechnol., 38(2), 2000, p. 121.

15. *** UV/VIS Spectroscopy, http://www.upv.es/herme/files/3b-uv-visspectroscopy.pdf.

16. *** ATLAS-A Bedside Scoring System Predicting Mortality Due to Clostridium Difficile Infection (CDI) in Elderly Hospitalized Patients, https://idsa.confex.com/idsa/2010/webprogram/Paper4263.html.

17. *** Charlson Comorbidity Index (CCI), https://www.mdcalc.com/ charlson-comorbidity-index-cci.

18. *** Bristol stool scale, https://www.continence.org.au/

Manuscript received: 28.09 .2019 